\title{
Música, sociabilidade e memória
}

\author{
Adriana Fernandes \\ Professora da UFPB \\ afernanda@terra.com.br \\ FLÁVIA PEDREIRA \\ Professora da UFRN \\ flaviaped@uol.com.br \\ Maria Amélia Alencar \\ Professora da UFG \\ ameliaalencar@cultura.com.br \\ Sebastião Rios \\ Professor da UFG \\ sebastiaorios@terra.com.br
}

$\mathrm{C}$

om a ORganizaÇão do dossiê temático Música, Sociabilidade e

Memória nos propomos a discutir e aprofundar o entendimento da experiência musical - que envolve o fazer musical, seu registro, difusão e recepção -, de uma perspectiva transdisciplinar, investigando seu papel na conformação das sensibilidades e, conseguintemente, das formas de sociabilidade e sua memória.

As experiências musicais constituem eventos que conjugam as sensibilidades do indivíduo e da coletividade, compondo um tecido social denso de significados. Por meio dessas experiências, os indivíduos desenvolvem e estabelecem formas de conhecimento e entendimento das realidades nas quais estão imersos. E elas afetam e modificam tanto o indivíduo, seu comportamento e sua visão do mundo como o contexto sociocultural onde ocorrem, no que adquirem uma dimensão política - entendido o termo em sentido amplo.

Interessado no aprofundamento do entendimento sobre o assunto, este dossiê investiga a configuração de sensibilidades e de formas de sociabilidade e os processos de identificação e de construção da memória social por meio das experiências musicais. Com base em um olhar interdisciplinar, que congrega pesquisadores das áreas de Sociologia, Antropologia, História, Comunicação e Semiótica, são analisados o papel da música na conformação das sensibilidades e das formas de sociabilidade e ainda como suporte da memória e também o papel dos diferentes recursos midiáticos por meio dos quais a música é registrada, difundida e recebida - concertos, shows e happenings, internet, televisão, cinema, CDs, DVDs e LPs. Neste rol, entram também os lugares em que determinados tipos de música são executados e apreciados e que caracterizam um território cultural e social que tem grande implicação na constituição da identidade individual e cultural de grupos e tribos.

A construção da identidade individual e cultural, por sua vez, implica uma pluralidade de significados móveis e mutantes, que variam de acordo com as posições assumidas no e pelo grupo, e que comparecem nas diferenciações, conflitos e contradições que compõem a cena musical de uma determinada época e/ou lugar. Assim, os artigos contemplam também os conflitos inerentes ao 'campo musical' (Bourdieu, 1990), com sua distribuição desigual de capital simbólico, econômico e político. 
Com relação a este último tópico, o dossiê se revela igualmente interessante pelas ausências. Formado basicamente por cientistas sociais, num entendimento amplo da área, não apareceram contribuições voltadas a investigar as relações e imbricações possíveis entre as questões formais (instrumentação, arranjos, interpretação, temas, gêneros e estilos) e as questões socioculturais e políticas. Relevantes e instigantes, os textos consideram, todavia, aspectos extramusicais da música popular urbana brasileira (do centro ou da periferia, de cidades do interior ou de capitais, litorâneas ou do sertão) e de um ritual dos Javaé. E isso tanto tem a ver com as dificuldades inerentes à pesquisa interdisciplinar - especialmente quando envolve uma área tão específica como é o caso da música - como com as orientações da maioria dos cursos de graduação em música, voltados preponderantemente para a música erudita ocidental e seus aspectos performáticos.

Trata-se, claramente, de uma posição de poder dentro do campo. No cânone vigente, a música erudita ocidental é privilegiada e são estudadas preferencialmente as 'grandes obras' legadas pelos 'grandes compositores'. Desse modo, muitos conhecedores de música, formados nessas escolas e conservatórios, não se interessam ou não tem muita oportunidade institucional de trabalhar com as músicas que estão na rua, na internet, que tocam no rádio ou na TV - não raro porque muitas delas são mesmo questionáveis em termos tanto musicais como culturais. No entanto, a enorme circulação de bens culturais e simbólicos na atualidade coloca, entre várias outras indagações, a questão das outras músicas e até mesmo da definição do que é considerado música e por quem. E isso abre toda uma discussão dos aspectos filosóficos, culturais, sociais, econômicos, políticos - extramusicais, portanto - que interessam em primeira mão aos cientistas sociais, mas que seria também de muito proveito para os músicos.

Essa situação leva ao estabelecimento de contendas referentes às experiências musicais, tanto para aqueles que fazem música como para os que a ouvem, já que estes também vivem uma experiência musical quando são estimulados pelos sons. Daqui já podemos estabelecer um primeiro parâmetro para situar a música na contemporaneidade - a escuta musical constitui antes de mais nada uma experiência física que envolve todos os sentidos e não apenas a audição. Ela é vivida de diferentes maneiras - pela dança, pela memória, pela apreciação, pelos estímulos à imaginação. E é, nesses termos, extremamente democrática, já que é acessível a todos e todas essas formas de vivenciá-la são igualmente formas de 'fixá-la', o que implica ir além da fixação nas diversas mídias ou na transcrição das partes.

O fenômeno musical ocorre de diferentes formas e compreende, além do som, idéias e comportamentos. Ele é vivenciado e entendido dentro de uma ampla margem de significados. Por que, então, especialmente em um país como o Brasil cujas matrizes sonoras são as mais diversas, privilegiar um tipo de música e uma matriz em detrimento de outras. Ir além da tradição ocidental é uma tarefa do momento, mas isso não implica recusá-la e nem desconsiderar sua enorme importância na conformação da música que se faz no país. Trata-se apenas de alargar as fronteiras e vislumbrar a pluralidade de sons, estilos e movimentos.

O conceito de música deve ser repensado e ampliado, acompanhando os novos conhecimentos sobre as músicas e sobre as sociedades que as praticam e a incorporação de contribuições de várias áreas que vão da Física (acústica) à Filosofia, Antropologia, Sociologia, História e outras mais. Tratar do fenômeno musical implica, assim, voltar a atenção para diversos aspectos: para a intenção de fazer música em oposição 
a outros tipos de sons; para a habilidade de formular linhas sonoras que sejam aceitas como música pelos membros de uma dada sociedade; para a construção e uso de instrumentos que produzem som; para os corpos que igualmente operam como produtores de som e que os acompanham; para as emoções despertadas pela produção, apreciação e participação em uma performance; para os próprios sons produzidos e seus canais de veiculação; para as formas de valorização e julgamento que passam pela história e pelas percepções de classe, gênero, geração, pertencimentos (Seeger, 2004).

Toda essa complexidade pode ser apreendida por meio de experiências musicais que estão profundamente enraizadas em questões culturais e mais especificamente no reino das sensibilidades e das formas de sociabilidade. A experiência musical entendida como experiência sensível ocorre dentro de um arcabouço cultural de grande amplitude histórica e social. Pensar estas experiências implica assumir uma ampla gama de variedades e pluralidades sonoras, sem privilegiar qualquer tradição, mas trazendo todas para uma avaliação estética, cultural e social de suas qualidades e possibilidades de estruturar as formas de sociabilidade. E esta dimensão não deveria ser desprezada no próprio ensino de música.

As mudanças nos padrões musicais constituem indícios importantes dos rumos da mudança de uma sociedade e as alterações nos repertórios e na escuta são igualmente reveladores das formas de construção da identidade (Nettl, 2006). E isso é assunto do maior interesse para o estudo das relações entre música e as formas de sociabilidade. O contato com experiências musicais diversas e a incorporação de alguns de seus elementos - fato tão corriqueiro no mundo globalizado - tanto pode constituir uma estratégia de um estilo musical voltada para sua permanência e superação de ameaças à sua existência como pode implicar seu 'desvirtuamento' e 'descaracterização'. Em cada caso, estas interações precisam ser estudadas em suas relações específicas dentro do campo em que se encontram. É isso que este dossiê tenta fazer. Se tivemos sucesso na empreita e em que medida, já é algo que cabe ao leitor avaliar.

\section{Referências}

BOURDIEU, Pierre. O poder simbólico. Rio de Janeiro: Difel, 1990.

NETTL, Bruno. O estudo comparativo da mudança musical: estudos de caso de quatro culturas. Revista Anthropológicas. Recife, v. 17, n. 1, 2006, p. 11-34. SEEGER, A. Why Suyá sing: a musical anthropology of an amazonian people. Chicago: University of Illinois Press, 2004 [1987]. 